\title{
Variability in Detritus Stocks in Beds of the Seagrass Cymodocea nodosa
}

\author{
M. Pérez*, M. A. Mateo, T. Alcoverro and J. Romero \\ Departament d' Ecologia, Universitat de Barcelona, Diagonal 645, 08028 Barcelona, Spain \\ * Corresponding author
}

Detritus associated with the Mediterranean seagrass Cymodocea nodosa Ucria (Ascherson) can reach high values of dry weight per unit area and accumulate significant amounts of carbon, nitrogen and phosphorus. However, large differences appear between stands, even within a narrow (i. e. $10 \mathrm{~km}$ ) geographical range. In nutrient limiting conditions, well-developed stands (at least 5 years old, probably much more) show accumulation of large pools of below ground detritus, accounting for $15.8 \mathrm{~g} \mathrm{~N} \mathrm{~m}^{-2}$ and $0.94 \mathrm{gP} \mathrm{m}^{-2}$. Leaf decay rates are relatively slow $\left(\mathrm{k}=0.008 \mathrm{day}^{-1}\right.$, for experiments lasting ca. 80 days), allowing leaf debris to be exported. In young stands (up to 3 years old), below ground detritus is less abundant (accounting for $5.2 \mathrm{gN} \mathrm{m}^{-2}$ and $0.2 \mathrm{gP} \mathrm{m}^{-2}$ ). Therefore, during stand ageing, detritus pools significantly increase, acting as net nutrient sinks. In high nutrient conditions, detritus weight per unit area is small, as is element storage $\left(8.6 \mathrm{gN} \mathrm{m}^{-2}\right.$ and $0.71 \mathrm{gP} \mathrm{m}^{-2}$ ) and this is due not only to the lower production of roots and rhizomes under these conditions, but also to the high decay rates (decay rates for leaves, $\mathrm{k}=0.015 \mathrm{day}^{-1}$ ). Therefore, when a seagrass bed is submitted to a moderate increase in nutrient availability (e. g. eutrophication), part of the nutrients stored is remobilized and the meadow behaves as a net source of nutrients during this process.

\section{Introduction}

Detritus plays key roles in seagrass ecosystems. For example, it is an essential pathway for the transfer of energy and matter from seagrasses to their consumers, and from seagrass beds to adjacent areas (Mann 1988). Many studies have elucidated specific aspects of dead organic matter dynamics (e. g. leaf litter decay, see Harrison 1989) and highlighted the role of detritus for shaping and feeding the trophic foodwebs associated with seagrass ecosystems (Klug 1980, Klumpp et al. 1989). However, only few studies have thrown light on the size of the detritus pools, their fate and their role in element budgets of seagrass ecosystems (e. g. Gallagher et al. 1984, Kenworthy and Thayer 1984, Pellikaan and Nienhuis 1988; Hemminga et al. 1991).

Recent studies on the dominant Mediterranean seagrass Posidonia oceanica (L.) Delile have quantified the rate of leaf litter export, in situ litter consumption and the role of below ground organs as sinks for biogenic elements (Romero et al. 1992, Romero et al. 1994, Mateo et al. 1997, Mateo and Romero 1997). They have confirmed the key role of detritus in element cycling and shown the high variability of carbon and nutrient fluxes within and outside the system, even within this single species. This variability is controlled by both 'internal' (e. g. nutrient concentration of leaves affects leaf litter decay rates) and 'external' factors (e. g. hydrodynamism determines the rate of detritus export). Further variability in such fluxes is expected to be found if different species are compared, as suggested by the very high interspecific variability found in some key parameters, such as leaf decay rates (e. g. Harrison 1989, Enríquez et al. 1993), or when other sources of variability are considered (stand age, i. e. time since colonisation, Pedersen et al. 1997). However, despite their functional and ecological relevance, these aspects have only partially been explored, and some key questions regarding the role of seagrass meadows in nutrient cycles remain partially unanswered. The seagrass Cymodocea nodosa (Ucria) Ascherson is dominant in sheltered, shallow places in the Mediterranean Sea, including areas with some freshwater input (Den Hartog 1970, Pérez and Camp 1986). In contrast to the slow-growing Posidonia oceanica, Cymodocea nodosa has a relatively fast growth rate, a high turnover and a low below ground biomass (Pérez and Romero 1994), and shows a remarkable growth and resource allocation plasticity (Pérez et al. 1994).

This work is a tentative attempt to explore the role of this species, as a paradigm of fast-growing seagrasses, in carbon and nutrient budgets of shallow coastal waters. To this end, we explore the capacity of its meadows to store $\mathrm{C}, \mathrm{N}$ and $\mathrm{P}$, both in the form of biomass and in the form of detritus, and the variability of this capacity as a function of stand age and under contrasting conditions of nutrient supply.

\section{Material and Methods}

\section{Study site and sampling design}

The work was performed in Els Alfacs Bay, a shallow (up to $6 \mathrm{~m}$ deep) estuarine bay on the north east coast 
of Spain (Fig. 1). The northern part of the bay receives freshwater inputs as runoff from rice paddy fields. The freshwater runoff has a high nutrient concentration $\left(\left[\mathrm{PO}_{4}\right]=2 \mu \mathrm{M} ;\left[\mathrm{NH}_{4}\right]+\left[\mathrm{NO}_{3}\right]=100 \mu \mathrm{M}\right.$, annual average, Delgado and Camp 1987, Prat et al. 1988), and establishes a gradient of nutrient availability between the northern nutrient-rich shore and the eastern and southern nutrient-poor shores. Average concentrations of inorganic nitrogen and inorganic reactive phosphate in the water column are ca. 30fold higher in the nutrient-rich zone than in the poor zone, while for pore water the values are 2-7 fold higher in the rich than in the poor zone (Vidal et al. 1992, Pérez et al. 1994). Further details on general features of this bay are given in Camp and Delgado
(1987) and Camp et al. (1991). The shallow parts of the bay (from 0.2 to $3 \mathrm{~m}$ deep) are covered by seagrasses mainly Cymodocea nodosa (Pérez and Camp 1986). On the $\mathrm{N}$ and NE shores, the seagrass distribution is continuous, while on the SE and $\mathrm{S}$ shores it is patchy (see Fig. 1), due to successive episodes of seagrass destruction and recolonization caused by active sand movement (Marbà and Duarte 1995).

Sampling was performed in a total of 20 stands distributed throughout the bay as follows:

a) 6 stands in the continuous meadows of the rich zone

b) 6 stands in the continuous meadows of the poor zone

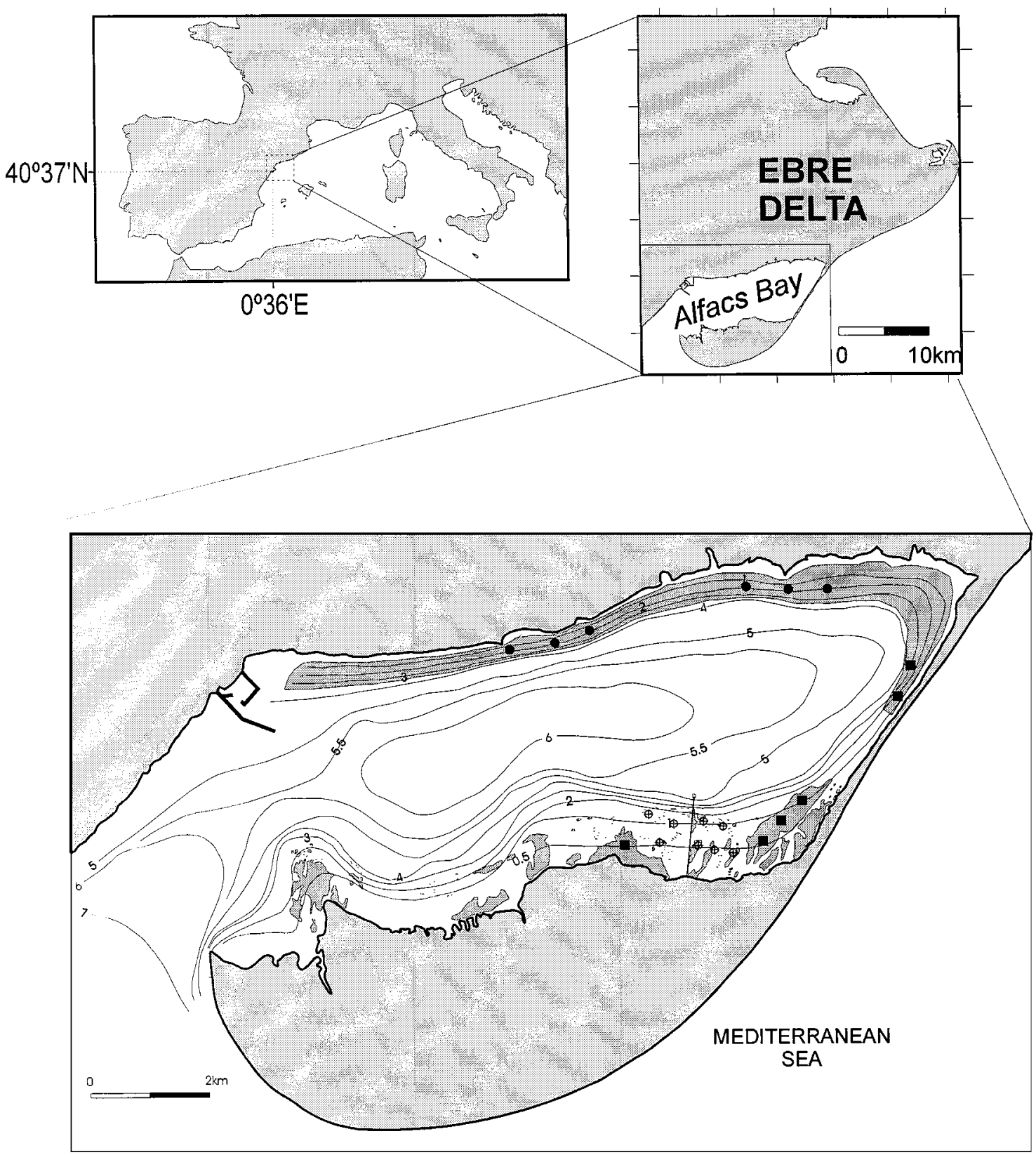

Fig. 1. Situation of the Alfacs bay in the Ebro Delta, and contour map of the Cymodocea nodosa beds. Sampling sites are indicated (black circles: old-rich; black squares: old-poor; grey circles: young-poor). 
c) 8 stands in small patches $\left(<10 \mathrm{~m}^{2}\right)$ or on the periphery of larger patches of the poor zone.

Within each of the three categories, stands were chosen at random, with a minimum distance of $100 \mathrm{~m}$ between stands to encompass the maximum withincategory variability. At each stand, and for age determination, all the shoots and rhizomes inside a $40 \times$ $40 \mathrm{~cm}$ quadrat were harvested (i. e. between 100 and 300 shoots examined). The age of shoots and rhizome fragments was determined in 1-year intervals, by taking into account the seasonal alternation of short and long internodes in horizontal rhizomes (as described in Caye and Meinesz 1985) and by counting the number of leaf scars and leaves on vertical rhizomes (Pérez and Romero 1994). Stand age was considered to be the age of the oldest shoot or rhizome fragment found within a sample.

The estimates of stand age ranged from 3 to 7 years old. In most of the samples from the continuous meadows (both in the rich and in the poor zones) the oldest rhizome found had an estimated age of 5 years (less frequently, 6 or 7 years); however, aerial photographs (Pérez and Camp 1986) have shown the persistence of continuous seagrass stands in the sampled areas for at least 20 years. Such underestimation is a consequence of the high shoot mortality (from 0.87 to 1.62 year $^{-1}$; Pérez et al. 1994), which results in a very low probability of finding old shoots for this sample size. In contrast, the oldest shoots found in samples from small patches or from the periphery of large patches were 3 (less frequently 4) years old. Since our purpose was not a precise determination of stand age, but merely to obtain a distinction between recently established and non-recent stands, we further consider as 'young' those stands with an estimated age of 2,3 or 4 years, and as 'old' those having an estimated age of 5 years or more, resulting in a sample distribution as indicated in Table I.

To assess the variability in detritus stocks due to nutrient availability, we compared the stands in the nutrient-rich zone (all of them 'old') to the old stands of the nutrient-poor zone. To assess the variability due to age, we compared young stands of the nutrient-poor zone to old stands of the same zone. The absence of identifiable age variability within the continuous seagrass bed of the rich zone precluded the study of the age effect there.

\section{Stocks evaluation}

Once stand age was evaluated, at each stand two replicate samples were taken with a hand-held corer device, $16 \mathrm{~cm}$ in diameter. The corer was pushed into the sediment to a depth of $20 \mathrm{~cm}$; from the resulting cylindrical sample, the top $\mathrm{cm}$ of the sediment was cut off, and all the litter found there (mostly, leaf litter) was carefully picked up and washed through $8 \mathrm{~mm}$ (coarse leaf litter) and $1 \mathrm{~mm}$ (fine leaf litter) sieves. The rest of the core was washed in seawater through a $3 \mathrm{~mm}$ sieve to remove the sediment. The following fractions were separated: living leaves, living rhizomes, dead rhizomes, living roots and dead roots; no leaf litter was found in this part of the sample. Living and dead parts were distinguished on the basis of connection to any plant part bearing green leaves.

To evaluate the relevance of the litter fraction between 1 and $3 \mathrm{~mm}$, additional samples were taken at three stands belonging to each of the three categories (old-rich, old-poor, young-poor); coarse and fine parts were separated as above (and discarded) and the remaining sediment sieved through a $1 \mathrm{~mm}$ mesh net. Such detritus were examined with a stereomicroscope, dried and weighed.

Sampling was performed in August, which is the time of the year the plant reaches its maximum biomass (Pérez and Romero 1994). However, since leaf production is clearly seasonal, we suspected that leaf detritus accumulation should follow suit. Therefore, to assess such seasonality, 6 samples were taken during one year at each one of the three stands belonging to the old nutrient-poor class and at three stands belonging to the old nutrient-rich class. To this purpose, we used the same core, slicing the first $\mathrm{cm}$ (as explained) and rejecting the rest.

All fractions were dried $\left(70^{\circ} \mathrm{C}\right.$ until constant weight) and weighed. Samples were kept for element analysis.

\section{Decay rates}

To assess leaf decay rates, litter bag experiments (Bocock et al. 1960, Godshalk and Wetzel 1978, Brock et al. 1985, Josselyn et al. 1986) were performed in the nutrient-rich and nutrient-poor zones of the bay. To elucidate the proxy causes of the possible variabil-

Table I. Main features of the different stands studied.

\begin{tabular}{lllllll}
\hline Zone & $\begin{array}{l}\text { Stands } \\
\text { sampled }\end{array}$ & N content in leaves & P content in leaves & $\begin{array}{l}\text { Age of } \\
\text { oldest } \\
\text { rhizome } \\
\text { (years) }\end{array}$ & $\begin{array}{l}\text { Probable } \\
\text { age }\end{array}$ & Stand class \\
& $(\mathrm{n})$ & $(\%)$ & $(\%)$ & 5 & $>5$ & old-rich \\
\hline $\mathrm{N}$ & 6 & $2.89 \pm 0.24$ & $0.182 \pm 0.02$ & $5-7$ & $>5$ & old-poor \\
S-SE & 6 & $2.04 \pm 0.12$ & $0.107 \pm 0.01$ & $3-4$ & $<5$ & young-poor \\
S-SE & 8 & $2.02 \pm 0.17$ & $0.107 \pm 0.02$ & 5 & 5 \\
\hline
\end{tabular}


ity in decay rates between these two zones (i. e. nutrient concentration in water $v s$ nutrient concentration in leaf tissues), leaves from the rich/poor zones were incubated at the rich/poor zones, resulting in four different experimental conditions. We prepared 24 net bags ( $1 \mathrm{~mm}$ mesh size) containing $30 \mathrm{~g}$ (fresh weight) of senescent leaves; half of the bags contained leaves from the rich zone, and the other half leaves from the poor zone. Senescent leaves were obtained by gently agitating standing shoots, in order to use only those leaves which were just about to shed. Then, at each zone, 12 bags (half of them with leaves from the highnutrient zone, the other half with leaves from the low-nutrient zone) were attached close to the sediment under the plant canopy, and 3 bags per experimental condition (chosen at random) retrieved 40 and 78 days after the beginning of the experiment.

After bag retrieval, the contents were taken to the laboratory, washed, dried $\left(70{ }^{\circ} \mathrm{C}\right.$ until constant weight) and weighed. Samples were kept for element analysis. Decay rates are expressed as the $k$ parameter of a negative exponential fit of the weight loss data (Wt and Wo, weights at time $t$ and 0 , respectively) against time (t) (Olson 1963):

$$
\mathrm{Wt}=\mathrm{Wo}^{-\mathrm{kt}} \text {. }
$$

\section{Export rates}

Leaf litter export was calculated by comparing seasonal data of leaf litter stocks to the values predicted from seasonal leaf fall data (Pérez and Romero 1994), corrected for leaf decay rates, if no export took place. This method, further described in Romero et al. (1992) and Pergent et al. (1994), assumes no losses (or, for practical purposes, only small losses) through herbivory. Although it would seem that Cymodocea nodosa suffers a relatively high herbivore pressure, in Alfacs Bay such pressure is only modest ( $7 \%$ of losses due to herbivory: Cebrián et al. 1996).

\section{Element analysis}

Element analysis was performed on sub-samples from the corer samples. Dry plant tissues were ground to a fine powder. The $\mathrm{C}$ and $\mathrm{N}$ concentrations were analysed using a Carlo-Erba CHN analyser, calibrated with appropriate standards. The P concentration was analysed by induced coupled plasma spectrometry (ICP) after a wet acid digestion in a microwave oven (Mateo and Sabaté 1993).

\section{Statistical analysis}

Variability in organic mass (biomass and detritus) and $\mathrm{C}, \mathrm{N}$ and $\mathrm{P}$ concentrations (dependent variables) was analysed using repeated-measure analysis of variance (ANOVA) for leaves, rhizomes and roots; independent variables were 'status' (living or dead, i. e. biomass $v s$ necromass, within-subjects) and stand class (young-poor, old-poor and old-rich, between subjects). Seasonality and among sites differences in leaf litter stocks were assessed using two-way (stand class and sampling date) ANOVA. Differences in decay rates between stand classes were tested using covariance analysis, with remaining weight (log-transformed) in the litter bags as the dependent variable, stand class as the independent variable and time as the covariate. When necessary, multiple comparisons among means were performed using the Tukey HSD test.

Table II. Summary of ANOVA performed on data from the core samples.

\begin{tabular}{|c|c|c|c|}
\hline Dependent variable & Leaves & Rhizomes & Roots \\
\hline $\begin{array}{l}\text { Dry weight } \\
\left(\mathrm{gDW} \mathrm{m}^{-2}\right)\end{array}$ & Stand class $* *(71 \%)$ & $\begin{array}{lr}\text { Status*** } & (58 \%) \\
\text { Stand class*** } & (24 \%) \\
\text { Interaction* } & (4 \%)\end{array}$ & Stand class** $(63 \%)$ \\
\hline $\begin{array}{l}\text { Carbon } \\
\text { ( } \% \text { of dry weight) }\end{array}$ & Stand class* $(59 \%)$ & Status*** & $\begin{array}{ll}\text { Status*** } & (49 \%) \\
\text { Stand class* } & (16 \%)\end{array}$ \\
\hline $\begin{array}{l}\text { Nitrogen } \\
\text { (\% of dry weight) }\end{array}$ & $\begin{array}{l}\text { Stand class* }(33 \%) \\
\text { Interaction** }(43 \%)\end{array}$ & $\begin{array}{l}\text { Stand class } * * *(43 \%) \\
\text { Interaction** }\end{array}$ & $\begin{array}{l}\text { Stand class } * * *(34 \%) \\
\text { Interaction*** }(15 \%)\end{array}$ \\
\hline $\begin{array}{l}\text { Phosphorus } \\
\text { (\% of dry weight) }\end{array}$ & $\begin{array}{ll}\text { Status** } & (13 \%) \\
\text { Stand class } * * & (53 \%)\end{array}$ & $\begin{array}{l}\text { Stand class*** }(35 \%) \\
\text { Interaction** }\end{array}$ & Stand class*** $(75 \%)$ \\
\hline
\end{tabular}

Four dependent variables were considered and analysed separately for the three main plant parts. Independent variables were "Stand class" (between subjects) and "Status" (i. e. living or dead, within subjects factor). Only independent variables explaining a significant amount of variability (in brackets, as a percentage of the total) are indicated $(*: 0.01<\mathrm{p} \leq 0.05$; $* *: 0.001<\mathrm{p} \leq 0.01 ; * * *: \mathrm{p} \leq 0.001)$. 


\section{Results}

Biomass and detritus stocks and $\mathrm{C}, \mathrm{N}$ and $P$ concentration in plant tissues

Significant differences in total standing dry weight (biomass plus necromass) were found among stand classes (including plant and detritus fractions; Table II and Fig. 2), with the highest values in old-poor stands (Tukey post-hoc test, $\mathrm{p}<0.001$ ). Rhizomes (living and dead) were, in general, the organ with the highest dry weight per unit area; the relative importance of each organ depended on the stand class, with the lowest values for roots in old-rich stands. Biomass exceeded necromass by $50 \%$ on average but de-

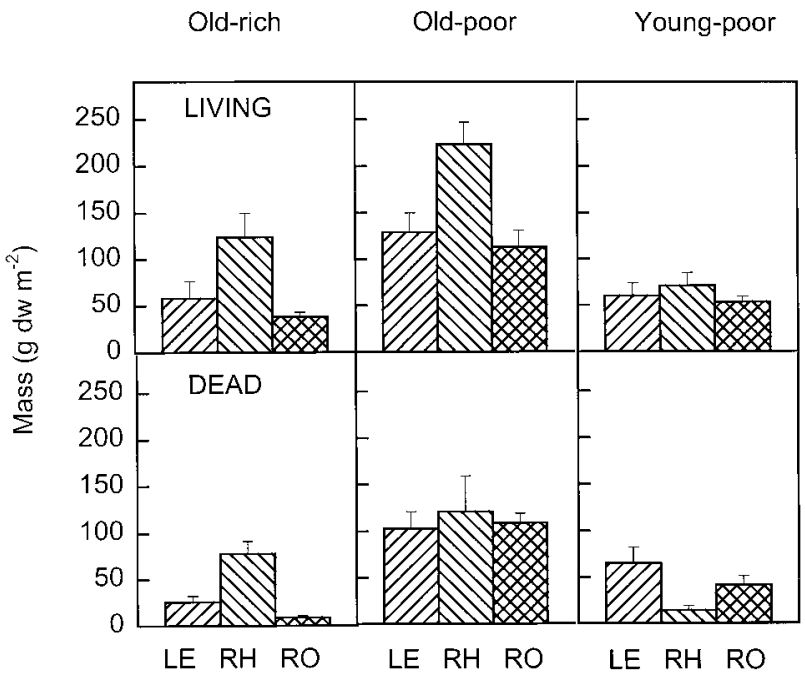

Fig. 2. Standing dry weight of the different plant parts, for either living or dead matter and for the three stand classes studied. LE: leaves; RH: rhizomes; RO: roots (vertical bars are the standard error of the mean).

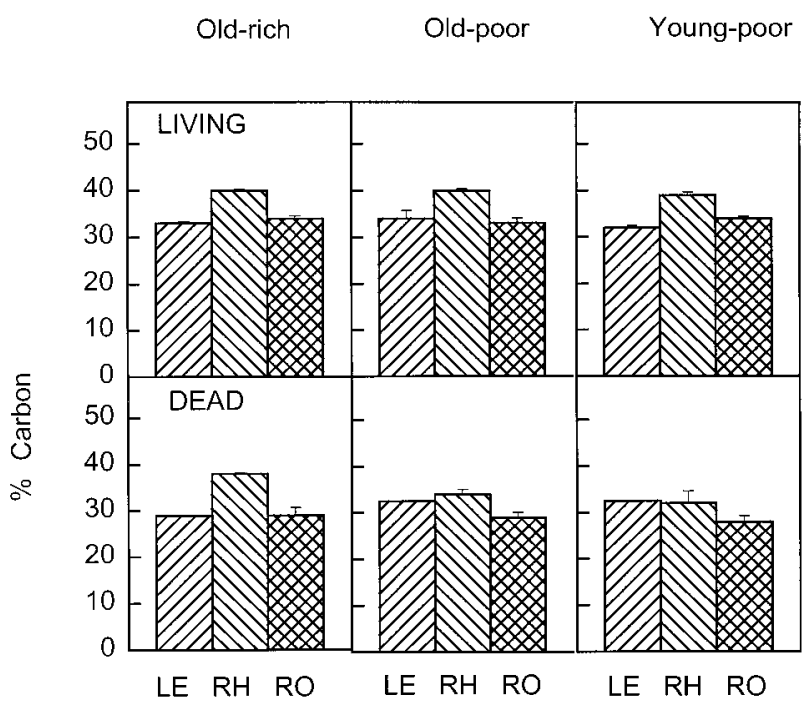

Fig. 3. Carbon concentration in the different plant parts, for either living or dead matter and for the three stand classes studied. LE: leaves; RH: rhizomes; RO: roots (vertical bars are the standard error of the mean). tritus accumulation depended on the plant part, with lower values for rhizome detritus than for its living counterparts.

Carbon concentration (Fig. 3) in the dead parts was lower than in the living ones, but the difference was small ( $8 \%$ on average) and only significant for roots and rhizomes (Table II). Carbon concentrations were higher in rhizomes than in leaves and roots. Differences between stand classes accounted for a large part of the variability in nitrogen tissue content (Table II, Fig. 4). Old-rich stands had the highest concentration, while young-poor ones had the lowest. Leaves had the highest $\mathrm{N}$ concentration and rhizomes the lowest, except in old-rich stands, where no significant differences were found. In old-rich stands, nitrogen concentration was lower in the dead parts than in the living ones, while the opposite occurred in the other two classes (as shown by the significant interactions between stand class and status, see Table II and Fig. 4).

Differences between stand classes also accounted for most of the variability in phosphorus tissue content (Table II, Fig. 5), and values were ordered as for $\mathrm{N}$ (old-rich > old-poor > young-poor). Maximum $\mathrm{P}$ concentration was found in rhizomes in oldrich stands, while leaves were the richest plant part in the other two stand classes. Leaf litter had a lower content of $\mathrm{P}$ than living leaves, although these differences explained only a small part of the variability (see Table II).

The fine below ground necromass (between 0.3 and $0.1 \mathrm{~cm}$ ) was mostly constituted by very tiny root fragments, and represented $6 \pm 2.5 \%$ (standard error, $n$ $=6)$ in old-rich stands, $36 \pm 17 \%(\mathrm{n}=10)$ in oldpoor stands, and less than $1 \%(n=3)$ in young-poor stands of dead root stocks.

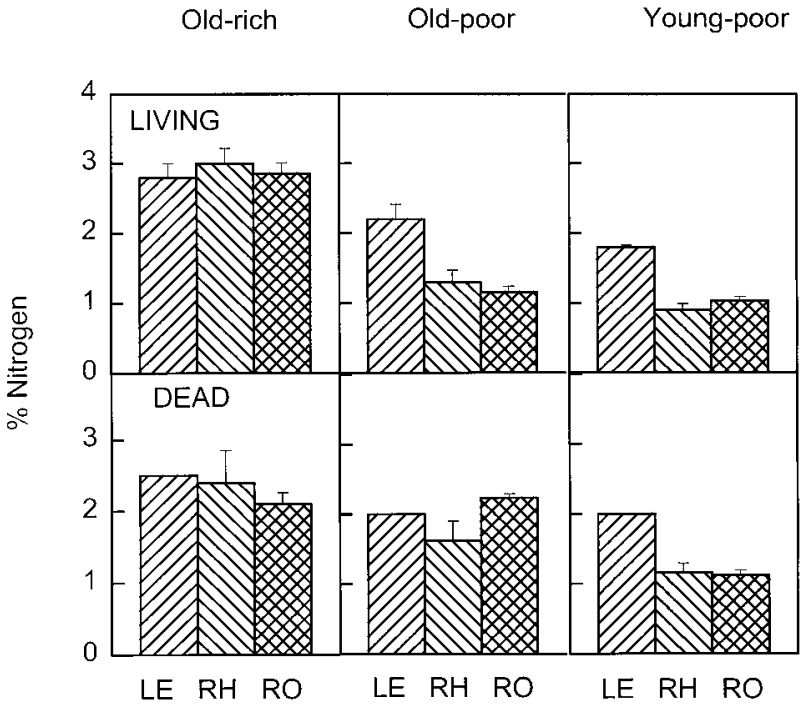

Fig. 4. Nitrogen concentration in the different plant parts, for either living or dead matter and for the three stand classes studied. LE: leaves; RH: rhizomes; RO: roots (vertical bars are the standard error of the mean). 
Leaf litter showed significant changes with time (Fig. 6), with maximum values in late summer and autumn, when leaf fall takes place, and minimum values during winter. Values were lower in old-rich stands than in old-poor ones. Fine leaf litter stocks showed less clear trends, with values between 0.5 and 2 -fold those of the coarse leaf litter; this fraction included, apart from fine leaf debris, other organic material from macroalgae and other sources. Observation of several samples $(n=5)$ of the fine fraction under the binocular microscope revealed that on average $50 \%$ of particles of fine litter (range: $20-80 \%$ ) corresponded to Cymodocea nodosa leaves.

\section{Decay rates}

Leaf decay rates were higher (about 2-fold) in leaves from the nutrient-rich zone than in those from the nutrient-poor zone $(p=0.007)$, irrespective of the site of incubation (incubation site and interaction did

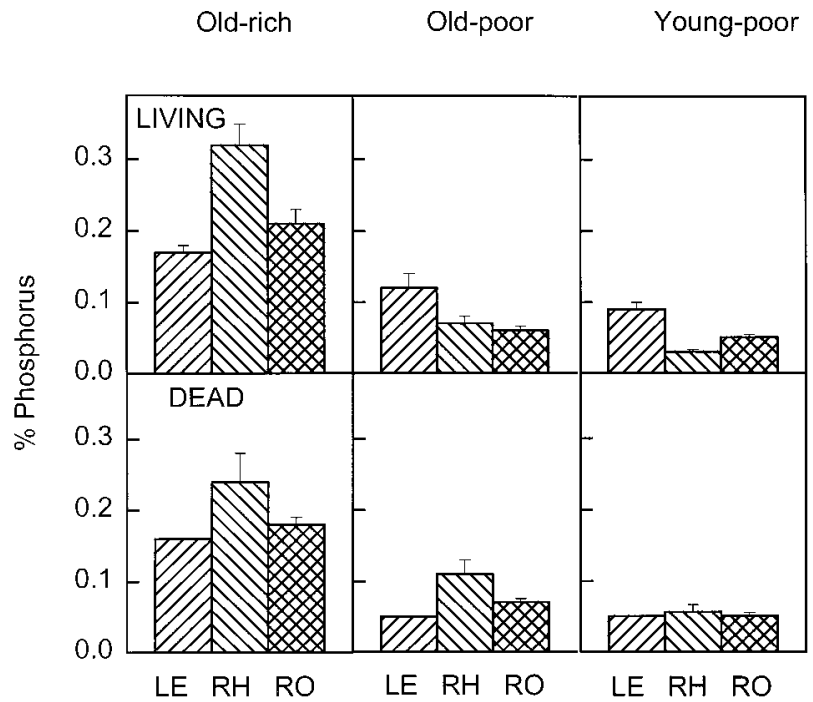

Fig. 5. Phosphorus concentration in the different plant parts for either living or dead matter and for the three stand classes studied. LE: leaves; RH: rhizomes; RO: roots (vertical bars are the standard error of the mean).

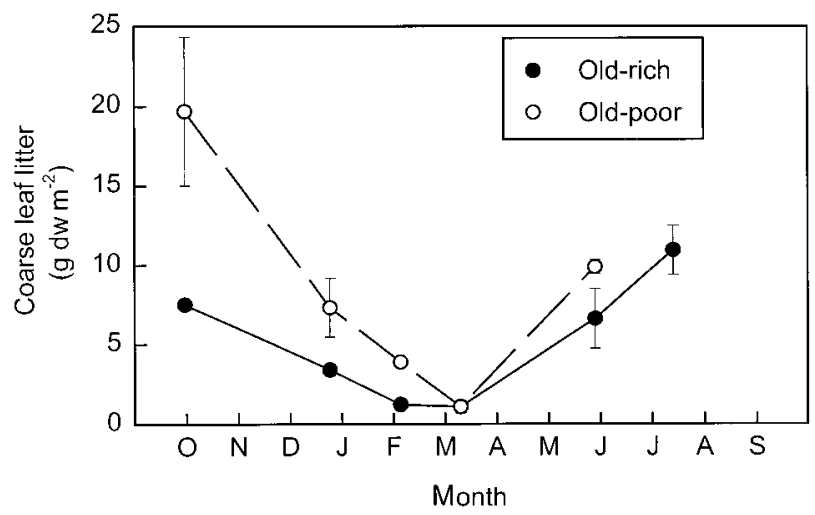

Fig. 6. Seasonal changes in leaf litter stocks (vertical bars are the standard error of the mean, $\mathrm{n}=3$ ). not explain a significant amount of the variability, Table III, Fig. 7).

\section{Export rates}

The estimates for export rates indicated that export was higher in old-poor stands than in old-rich stands (respectively, about $50 \%$ and $15 \%$ of primary production on an annual basis).

Since these estimates rely on relatively complex computations, to avoid spurious results we tested their sensitivity to the two most critical parameters, leaf litter stocks and leaf decay rates. Since most of the uncertainty associated with litter stocks evaluation results from the fact that only a part of the fine litter stock corresponds to seagrass leaves (the rest being allochthonous organic matter), we used for the computation the extreme values of the range found $(20-80 \%$, see above). Subsequent estimates of export rates were in the range of $9-23 \%$ for old-rich stands and $41-63 \%$ for old-poor stands. Sensitivity of the estimates to decay rates was tested using the obtained mean \pm one standard error (for each zone); subsequent estimates of export rates were within the range mentioned. Finally, and to ascertain whether or not differences in export rates between the two zones (rich and poor) were due to the different value of the leaf decay rate, we ran the estimates using a common

Table III. Decay rates of leaves estimated from in situ litter bags experiments.

\begin{tabular}{lllll}
\hline $\begin{array}{l}\text { Origin of } \\
\text { material }\end{array}$ & $\begin{array}{l}\text { Incuba- } \\
\text { tion site }\end{array}$ & $\begin{array}{l}\text { Duration } \\
(\text { days })\end{array}$ & $\begin{array}{l}\mathrm{k} \\
\left(\mathrm{d}^{-1}\right)\end{array}$ & $\begin{array}{l}\text { Standard } \\
\text { error }\end{array}$ \\
\hline poor & poor & 78 & 0.0091 & 0.0011 \\
rich & rich & 78 & 0.0146 & 0.0031 \\
poor & rich & 78 & 0.0081 & 0.0017 \\
rich & poor & 78 & 0.0167 & 0.0040 \\
\hline
\end{tabular}

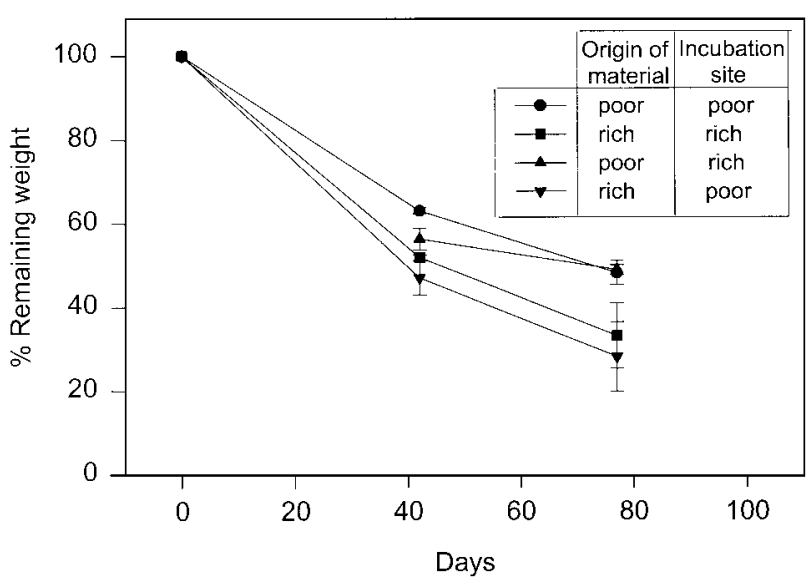

Fig. 7. Changes with time in the weight of leaf litter remaining in the litter bags (vertical bars are the standard error of the mean, $\mathrm{n}=3$ ). 
value for this parameter; differences in export rates between zones decreased to less than $5 \%$.

\section{Discussion}

The estimates of detritus stocks presented here do not consider particles less than $1 \mathrm{~mm}$ or other forms of particulate organic carbon (e. g. adsorbed to sediment). Organic content of the sediments in this area is in the range $5-10 \%$ (Pérez 1989), and, therefore, taking this bulk organic matter into account would have resulted in organic detrital carbon estimates considerably higher than those reported. Even if these additional organic pools originated from sources other than seagrasses (plankton, macroalgae, terrestrial detritus: see Gacia et al. 1999), the values presented here should be considered as conservative. Although being conservative, our results show that significant amounts of carbon and nutrients are accumulated as detritus. However, this accumulation exhibits great variability which, to a large extent within the sampled area, is due to nutrient availability and stand age.

Concerning nutrient availability, in waters with relatively high nutrient concentrations the detritus pools (in units of carbon or DW) are smaller than under low nutrient concentrations. Concerning leaf litter, this reduction in nutrient-rich stands relative to poor ones is caused by the decay rates of leaf litter from nutrient-rich stands that are clearly higher than those from litter from poor stands. Similar differences in decay rates between nutrient-rich and nutrient-poor environments have been found, and have been attributed either to nutrient availability in the water (Fenchel 1977, Valiela 1995) or to nutrient availability in the plant tissues (Wieder and Lang 1982, Harrison 1989, Enríquez et al. 1993), stimulating in both cases bacterial growth and activity. For the species studied here, our data clearly demonstrates the importance of internal nutrient concentrations as a control of leaf decay rates. Rapid leaf decay has further consequences on the elemental budget of the seagrass meadow, being responsible for the low export rates found in rich stands. Leaf litter export is mostly driven by episodic hydrodynamic events, and hence high decay rates decrease the probability of being carried outside the meadow. We can thus consider nutrients as indirect but effective mediators not only of leaf litter pools, but also of export rates.

The below ground detritus pools are also lower in rich stands (Fig. 2), but this cannot be attributed to hypothetically (by analogy with leaves) higher decay rates of below ground organs. Instead, the reduction in below ground biomass and production seems to be the main cause. As shown by Pérez et al. (1994), the increase in nutrient availability reduces the resource allocation by the plant to rhizomes and roots, decreasing the below ground production of detritus.
Concerning stand age within the nutrient poor zone, biomass increased from young to old stands, which seems to be a common feature of stand ageing (Pedersen et al. 1997). From young to old stands, both live rhizomes and roots increase their biomass by a factor of 2 , while the corresponding necromasses increase by a factor of 3 (roots) or 4 (rhizomes). This means that, apart from biomass increases due to colonisation and stand ageing, there is also a net accumulation of below ground detritus due to the imbalance between detritus production and decay. In effect, detritus production is independent of the detritus pool size, while detritus decay (not its rate, but its absolute value) is dependent on it: the higher the amount of detritus (e. g. in $\mathrm{gDW} \mathrm{m}^{-2}$ ), the higher the decay (e. g. in gDW m ${ }^{-2}$ year $^{-1}$ ). Therefore, in recently established stands with no, or very small, detritus stocks detritus production will exceed detritus decay, resulting in a net detritus accumulation. In the first phases of stand ageing, the seagrass meadow will thus behave as a net sink of elements. This accumulation (as plant-bound elements) has been estimated as $1.8 \pm 0.6 \mathrm{gN} \mathrm{m}^{-2}$ year $^{-1}$ and $0.1 \pm 0.03 \mathrm{gP} \mathrm{m}^{-2}$ year ${ }^{-1}$ by Pedersen et al. (1997), which agrees with the stocks reported here for $2-4$ year old stands $\left(5.2 \mathrm{gN} \mathrm{m}^{-2}\right.$ and $0.2 \mathrm{gP} \mathrm{m}^{-2}$, combining data of Figs 3,5 and 6 ).

However, the ability of this seagrass to trap excess nutrients should be viewed with caution. On the one hand, it is reasonable to assume that the accumulation of nutrients should have a limit or maximum. This limit (at least regarding plant-bound nutrients) is probably close to the values found in the old nutrientpoor stands (maximum values in the studied area), where the stocks were $15.8 \mathrm{gN} \mathrm{m}^{-2}$ and $0.94 \mathrm{gP} \mathrm{m}^{-2}$ (i. e. 3-4-fold higher than those from young stands). This limit will be reached when detritus production and detritus decay are more or less balanced; at which point the stand will no longer accumulate nutrients and will no longer be a sink, except, maybe, due to other processes, such as denitrification or accumulation of refractory $\mathrm{N}$ forms (see for example Pellikaan and Nienhuis 1988).

On the other hand, this storing capacity is only found where water nutrient concentrations are low to moderate [e. g. values close to those found in the poor zone: around $3 \mu \mathrm{M}\left(\mathrm{NH}_{4}+\mathrm{NO}_{3}\right)$ and $0.08 \mu \mathrm{M}$ $\left(\mathrm{PO}_{4}\right)$, Pérez et al. 1994]. Where large amounts of nutrients become available, [as in the rich zone, ca. $100 \mu \mathrm{M}\left(\mathrm{NH}_{4}+\mathrm{NO}_{3}\right)$ and $2 \mu \mathrm{M}\left(\mathrm{PO}_{4}\right)$, Pérez et al. 1994] the storage capacity decreases (values of $8.6 \mathrm{gN} \mathrm{m}^{-2}$ and $0.71 \mathrm{gP} \mathrm{m}^{-2}$ ), due to enhanced leaf decay rates and lower production rates (and hence, necromass) of below ground parts.

This suggests that if a eutrophication process takes place above a given threshold of nutrient load, seagrass meadows will shift from a sink to a source of nutrients, releasing in the order of $7.2 \mathrm{gN} \mathrm{m}^{-2}$ and $0.23 \mathrm{gP} \mathrm{m}^{-2}$ (i. e. the difference between stocks of 
plant-bound nutrients in old-poor and old-rich stands) and up to $15.8 \mathrm{gN} \mathrm{m}^{-2}$ and $0.94 \mathrm{gP} \mathrm{m}^{-2}$ (total stocks in old-poor stands) if, finally, seagrass disappears.

The potential shift in the role of seagrasses from sinks to sources of nutrients suggested by our data would probably apply to other seagrass species with characteristics similar to Cymodocea nodosa, especially high rhizome-root decay rates (e. g. Zostera marina L., see Kenworthy and Thayer 1984). However, other seagrasses that have very low rhizome decay rates with remarkably long-term rhizome detritus accumulation, such as Posidonia sp. (Shepherd and Spring 1976, Mateo et al. 1997) and Thalassodendron ciliatum (Forsk.) den Hartog (Lipkin 1979), are much more persistent sinks of carbon and nutrients (Cebrián and Duarte 1995).

Finally, the findings reported here stress the need for some caution when assessing the role of sea-

\section{References}

Bocock, K. L., O. J. Gilbert, C. K. Capstick, D. C. Turner, J. S. Ward and M. J. Woodman. 1960. Changes in leaf litter when placed on the surface of soils with contrasting humus types. J. Soil Science 11: 1-9.

Brock, T. C. M., J. J. Boon and B. G. P. Paffen. 1985. The effects of the season and of water chemistry on the decomposition of Nymphaea alba L.; weight loss and pyrolisis mass spectometry of the particulate matter. Aquatic Botany 22: 197-229.

Camp, J. and M. Delgado. 1987. Hidrografía de las bahías del Delta del Ebro. Investig. Pesq. 51(3): 351-369.

Camp, J., J. Romero, M. Pérez, M. Vidal, M. Delgado and A. Martínez. 1991. Production-consumption budget in an estuarine bay: how anoxia is prevented in a forced system. Oecologia aquatica 10: 145-152.

Caye, G. and A. Meinesz. 1985. Observations on the vegetative development, flowering and seedling of Cymodocea nodosa (Ucria) Ascherson on the Mediterranean coast of France. Aquatic Botany 22: 277-289.

Cebrián, J. and C. M. Duarte. 1995. Plant growth-rate dependence of detrital carbon storage in ecosystems. Science 268 (5217): 1606-1608.

Cebrián, J., C. M. Duarte and N. Marbà. 1996. Herbivory on the seagrass Cymodocea nodosa (Ucria) Ascherson in contrasting Spanish Mediterranean habitats. J. Exp. Mar. Biol. Ecol. 204(1-2): 103-111.

Delgado, M. and J. Camp. 1987. Abundancia y distribución de nutrientes inorgánicos disueltos en las bahías del delta del Ebro. Investig. Pesq. 51(3): 427-441.

Den Hartog, C. 1970. The Seagrasses of the World. Verhand. Kon. Ned. Akad. Wetensch. Afd. Natuurkunde, Tweede Reeks, deel 59. North-Holland Publ., Amsterdam. pp. 275.

Enríquez, S., C. M. Duarte and K. Sand Jensen. 1993. Patterns in decomposition rates among photosynthetic organisms. The importance of detritus $\mathrm{C}, \mathrm{N}, \mathrm{P}$ content. Oecologia 94: 457-471.

Fenchel, T. 1977. Aspects of decomposition of seagrasses. In: (C. P. McRoy and C. Helfferich, eds). Seagrass Eco- grasses at the ecosystem level, since it is clear that within a relatively narrow spatial range (a few kilometres) and within a geomorphologically well-delimited unit the same species can have the opposite behaviour in the net element budget of the system.

\section{Acknowledgements}

We are grateful to Pere Borrull, Cristina Sánchez and Quim Garrabou for their enthusiastic help during field work. Jordi Camp provided advice and expertise during the sampling programme. Financial support came from the CICYT grant CEE89-0017. Elemental analyses were performed by the Serveis CientíficoTècnics de la Universitat de Barcelona.

Accepted 29 March 2001.

systems: a Scientific Perspective. Dekker, New York. pp. $132-145$.

Gacia, E., T. C. Granata and C. Duarte. 1999. An approach to measurement of particle flux and sediment retention within seagrass (Posidonia oceanica) meadows. Aquatic Botany 65: 255-268.

Gallagher, J. L., H. V. Kirby and K. V. Skirvin. 1984. Detritus processing and mineral cycling in seagrass (Zostera) litter in an Oregon salt marsh. Aquatic Botany 20: 97-108.

Godshalk, G. L. and R. G. Wetzel. 1978. Decomposition of aquatic angiosperms. III. Zostera marina L. and a conceptual model of decomposition. Aquatic Botany 5: $329-354$.

Harrison, P. G. 1989. Detrital processing in seagrass systems: a review of factors affecting decay rates, remineralization and detritivory. Aquatic Botany 23: 263-288.

Hemminga, M. A., P. G. Harrison and F. van Lent. 1991. The balance of nutrient losses and gains in seagrass meadows. Mar. Ecol. Prog. Ser. 71: 85-96.

Josselyn, M., M. Fonseca, T. Niesen and R. Larson. 1986. Biomass, production and decomposition of a deepwater seagrass Halophila decipiens Ostenfeld. Aquatic Botany 25: $47-61$.

Kenworthy, W. J. and G. W. Thayer. 1984. Production and decomposition of the roots and rhizomes of seagrasses, Zostera marina and Thalassia testudinum, in temperate and subtropical marine ecosystems. Bull. Mar. Sci. 35: $364-379$.

Klug, M. J. 1980. Detritus-decomposition relationships. In: (R. C. Phillips and C. P. McRoy, eds). Handbook of Seagrass Biology: an Ecosystem Perspective. Garland STPM Press, New York. pp. 225-245.

Klumpp, D. W., R. K Howard and D. A. Pollard. 1989. Trophodynamics and nutritional ecology of seagrass communities. In: (A. W. D. Larkum, E. A. J. McComb and S. A. Shepherd, eds). Biology of Seagrasses. A Treatise on the Biology of Seagrasses with Special Reference 
to the Australian Region. Elsevier, Amsterdam. pp. 394457.

Lipkin, Y. 1979. Quantitative aspects of seagrass communities, particularly those dominated by Halophila stipulacea, in Sinai (Northern Red Sea). Aquatic Botany 7: $119-128$.

Mann, K. H. 1988. Production and use of detritus in various freshwater, estuarine and coastal ecosystems. Limnol. Oceanog. 33(4): 910-930.

Marbà, N. and C. M. Duarte. 1995. Coupling of seagrass (Cymodocea nodosa) patch dynamics to subaqueous dune migration. J. Ecol. 83: 381-389.

Mateo, M. A. and J. Romero. 1997. Detritus dynamics in the seagrass Posidonia oceanica: elements for an ecosystem carbon and nutrient budget. Mar. Ecol. Prog. Ser. 151: $43-53$.

Mateo, M. A. and S. Sabaté. 1993. Wet digestion of vegetable tissue using a domestic microwave oven. Analytical Chemical Acta 279: 273-279.

Mateo, M. A., J. Romero, M. Pérez, M. Littler and D. Littler. 1997. Dynamics of millenary organic deposits resulting from the growth of the Mediterranean seagrass Posidonia oceanica. Est. Coast. Shelf Sci. 44: 103-110.

Olson, J. S. 1963. Energy storage and the balance of producers and decomposers in ecological systems. Ecology 44(2): 322-331.

Pedersen, M. F., C. M. Duarte and J. Cebrián. 1997. Rates of changes in organic matter and nutrient stocks during seagrass Cymodocea nodosa colonization and stand development. Mar. Ecol. Prog. Ser. 159: 29-36.

Pellikaan, J. C. and P. H. Nienhuis. 1988. Nutrient uptake and release during growth and decomposition of eelgrass Zostera marina $\mathrm{L}$. and its effects on the nutrient dynamics of Lake Grevelingen. Aquatic Botany 30: 189-214.

Pérez, M. 1989. Fanerógamas marinas en sistemas estuáricos: producción, factores limitantes y algunos aspectos del ciclo de nutrientes. Ph. D. thesis. University of Barcelona.

Pérez, M. and J. Camp. 1986. Distribución espacial y biomasa de las fanerógamas marinas de las bahías del delta del Ebro. Investig. Pesq. 50: 519-530.
Pérez, M. and J. Romero. 1994. Growth dynamics, production and nutrient status of the seagrass Cymodocea nodosa in a Mediterranean semi-estuarine environment. P. S. Z N.I: Marine Ecology 15(1): 51-64.

Pérez, M., C. M. Duarte, J. Romero, K. Sand-Jensen and T. Alcoverro. 1994. Growth plasticity in Cymodocea nodosa stands: the importance of nutrient supply. Aquatic Botany 47: 249-264.

Pergent, G., J. Romero, C. Pergent-Martini, M. A Mateo and C. F. Boudouresque. 1994. Primary production, stocks and fluxes in the Mediterranean seagrass Posidonia oceanica. Mar. Ecol. Prog. Ser. 106: 139-146.

Prat, N., I. Muñoz, J. Camp, F. A. Comin, J. R. Lucena, J. Romero and M. Vidal. 1988. Seasonal changes in particulate organic carbon and nitrogen in the river and drainage channels of the Ebro Delta (N. E. Spain). Verh. Internat. Verein. Limnol. 23: 1344-1349.

Romero, J., G. Pergent, C. Pergent-Martini, M. A. Mateo and C. Regnier. 1992. The detritic compartment in a Posidonia oceanica meadow: litter features, decomposition rates and mineral stocks. P. S. Z N.I. Marine Ecology 13(1): 69-83.

Romero, J., M. Pérez, M. A. Mateo and E. Sala. 1994. The belowground organs of the Mediterranean seagrass Posidonia oceanica as a biogeochemical sink. Aquatic Botany 47: $13-19$.

Shepherd, S. A. and R. C. Sprigg. 1976. Substrate, sediments and subtidal ecology of Gulf St Vincent and Investigator Strait. In: (Twidale, C. R., M. J. Tyler and B. P. Webb, eds). Natural History of the Adelaide Region. Royal Society of South Australia, Adelaide. pp. $161-174$.

Valiela, I. 1995. Marine Ecological Processes. Springer, New York. pp. 686.

Vidal, M., J. A. Morgui, M. Latasa, J. Romero and J. Camp. 1992. Factors controlling spatial variability in ammonium release within an estuarine bay (Alfacs Bay, Ebro Delta, NW Mediterranean). Hydrobiologia 235/ 236: 519-525.

Wieder, R. K. and G. E. Lang. 1982. A critique of the analytical methods used in examining decomposition data obtained from litter bags. Ecology 63: 1636-1642. 